\title{
Comparable-Worth Wage Adjustments and Female Employment in the State and Local Sector
}

\author{
Ronald G. Ehrenberg, Cornell University and National \\ Bureau of Economic Research
}

Robert S. Smith, Cornell University

Our paper simulates the likely effects of a comparable-worth wageadjustment policy in the state and local sector on female employment in the sector. The simulation is based on estimates of withinoccupation male/female substitution and across-occupation occupational employment substitution that we obtain using data from the 1980 Census of Population.

\section{Introduction}

Some two decades after the passage of the Equal Pay Act of 1963 and Title VII of the 1964 Civil Rights Act, which together prohibit (among other things) sex discrimination in wages on any given job and sex discrimination in access to employment opportunities, it is still common to observe that on average females earn less than males, females are distributed across occupations in a quite different manner than males, and earnings in occupations that are dominated by females tend to be

We are most grateful to Daniel Sherman and Richard Chaykowski for their research assistance and to Eileen Driscoll and Ann Gerken for their assistance in obtaining and manipulating the census of population files used in the paper. Without implicating them for what remains, we are grateful to numerous colleagues for their comments on earlier drafts. 
lower than earnings in those dominated by males, even after controlling for traditional proxies for productivity. ${ }^{1}$ The frustrations generated by these outcomes have led to pressure for the adoption of the principle of comparable worth, a principle that at least one participant in the debate has called "the women's issue of the 1980s."

Put in simplest terms, proponents of comparable worth assert that jobs within a firm can be valued in terms of the skill, effort, and responsibility they require as well as of the working conditions they offer. Two jobs would be said to be of comparable worth to a firm if they were comparable in terms of these characteristics. The principle of comparable worth asserts that, within a firm, jobs that are of comparable worth to the firm should receive equal compensation.

While some efforts to implement comparable worth have taken place in the private sector, the major push for comparable worth has occurred in the state and local government sector. ${ }^{3}$ By the mid-1960s over a dozen states had passed comparable-worth legislation covering state employees, although these laws were rarely enforced. Starting with a 1974 Washington State study, a number of states have undertaken formal job-evaluation studies to see how their compensation systems mesh with the principle of comparable worth. In several cases, this has led to "voluntary" implementation of comparable worth through the legislative and collective-bargaining processes (e.g., in Minnesota) or to federal court-ordered implementation (in Washington). ${ }^{4}$ Comparable worth initiatives have also been undertaken at the local level in numerous jurisdictions. Indeed, Minnesota passed a law in April 1984 requiring political subdivisions to do job evaluations and then to revise their compensation structure in accord with the principle of comparable worth.

${ }^{1}$ See, e.g., Treiman and Hartmann (1981).

${ }^{2}$ This statement is attributed in a number of places to former Equal Employment Opportunity Commission chair Eleanor Holmes Norton.

${ }^{3}$ For evidence of the spread of comparable worth in the state and local sector, see Cook (1983), National Committee on Pay Equity (1984), and Ehrenberg and Smith (in press). Explanations offered for why this push has occurred in the public sector include that public decision makers are more likely to be swayed by public opinion calling for such policies than are private profit-maximizing firms and that females represent a larger share of employment in the public than in the private sector. With respect to the latter point, payroll data from Employment and Earnings (U.S. Department of Labor 1983, tables B1, B3) indicate that $51.2 \%$ of all state and local government employees were females in 1982; the comparable figures for manufacturing and the total private nonagricultural sector were $31.9 \%$ and $42.6 \%$, respectively.

${ }^{4}$ In AFSCME v. State of Washington (770 F.2d 1401 [9th Cir. 1985]). This order was subsequently overturned by a federal court of appeals; the state and the union then entered into a voluntary agreement in February 1986 to begin to implement comparable worth effective April 1, 1986. 
Given the growing importance of the concept of comparable worth in the state and local sector, an empirical analysis of some of the issues it raises is obviously in order. This paper focuses on a side effect of implementing comparable worth in the public sector that was not anticipated by comparable worth's proponents. Comparable-worth wage adjustments (CWWA) would likely alter at least four types of relative wages that public employers face. First, for any given function (e.g., police protection) and within any major occupational group (e.g., clerical) the average wage of female employees (e.g., secretaries) would rise relative to the average wage of male employees (e.g., radio dispatchers), as some female employees would be in the detailed occupational group (e.g., secretaries) that received CWWA. Second, for any given function (e.g., police), across major occupational groups, the average wage of employees in heavily "female" occupations (e.g., clerical) would rise relative to the average wages of employees in heavily "male" occupations (e.g., patrolmen), as more employees in the former would be in the detailed occupational groups that received CWWA. Third, across functions, the average wage in heavily female-dominated functions (e.g., health and welfare) would rise relative to the average wage in heavily male-dominated functions (e.g., fire protection), as employees in the former would again be more likely to be in the detailed occupations that received CWWA. Finally, holding constant the existing distribution of public employees, the average wage of public employees would rise relative to the prices of other goods and services.

It is natural to ask how such relative wage changes would affect the level and composition of public employment. To the extent that public employers' employment decisions are sensitive to their employees' wage rates, one would expect to observe the four types of relative wage changes leading, respectively, to the substitution of some male for some female employees within a function-occupation group, the substitution of some employment in male-dominated occupations for some employment in female-dominated occupations (within a function), the substitution of some employment in male-dominated functions for some employment in female-dominated functions, and a decline in the aggregate level of public employment. For all these reasons, CWWA might be expected to lead to a decline in female employment.

We should stress that the first two of these adjustments potentially occur because males and females may be substitutable in producing a given public service, the third potentially occurs because public-sector decision makers believe various public services are substitutable in producing utility for taxpayers/voters, and the fourth potentially occurs because public-sector decision makers believe that public services as a group are substitutable with private consumption in producing utility for taxpayers/voters. Hence, even if males and females are not substitutable 
in the production of any given public service, comparable-worth wage adjustments might still lead to a decline in female employment in the sector through their effects on the overall level and functional composition of public employment. Previous research does in fact indicate that the overall level and functional composition of state and local government employment are sensitive to public employee wage rates. ${ }^{5}$

One can, however, plausibly conceive of within-function withinmajor-occupation male/female substitution possibilities and within-function across-major-occupation substitution possibilities in the state and local sector. For example, within the police clerical category, increased wages for secretaries (who are predominantly female) relative to the wages of radio dispatchers (who are often male) might lead to substitution of the latter for the former, as dispatchers might be required to type more of their own "paperwork" during slack periods. Similarly, again looking at police but this time across major occupation groups, increases in the average wage of civilian clerical workers (who are predominantly female) relative to patrolmen (who are predominantly male) might lead to substitution of the latter for the former, as patrolmen might be expected to handle more of their own paperwork.

Of course, to say that one can conceive of such substitution possibilities does not mean that they actually occur. The state and local sector is heavily unionized, and union contract restrictions or civil service hiring systems in which position descriptions are narrowly defined may reduce the possibility of such forms of substitution occurring. As a consequence, Section II of this paper provides estimates of the extent to which these types of substitution actually occur in the state and local sector. Specifically, estimates of within-occupation male/female substitution and across-occupation occupational employment substitution are obtained, using data from the 1980 Census of Population. On the basis of these estimates and existing estimates of the demand for labor in the public sector, a crude simulation of the potential effects of CWWA on female employment in the public sector is presented in Section III. Finally, Section IV summarizes our findings and presents some brief concluding remarks.

\section{Across-Occupation Substitution and Within-Major- Occupation Gender Substitution in the State and Local Government Sector}

Our research strategy is to infer, from cross-sectional data on variations in state and local government employment and wage patterns across

${ }^{5}$ See, e.g., Ashenfelter and Ehrenberg (1975) and the more recent references cited in Ehrenberg and Schwarz (in press). Note that, as long as the total state and local government employment budget does not increase by as much as the increase in the average wage of state and local government employees caused by CWWA, total employment in the sector must fall. 
geographic areas, the extent to which state and local government employers substitute across major occupational categories as relative occupational wages change and substitute between males and females within a major occupational category as relative gender wages change. To perform such analyses, we require at a minimum estimates of state and local government employment and wages, by occupation and gender, disaggregated by state (for state employees) and by local area (for local government employees). The Census of Government does not fit our needs because it does not provide employment and wage data on an occupation or gender basis. Most national samples of individuals that provide employment and wage data along with occupation and gender information (e.g., the monthly Current Population Sample or the Panel Study of Income Dynamics) are also inappropriate because their sample sizes are much too small to calculate meaningful employment and average wage data for public employees by occupation, gender, and geographic area.

As a result, our analyses use data from the largest recent publicly available data source that contains the necessary variables, the " $\mathrm{A}$ " sample of the 1980 Census of Population. The A sample is a 5\% sample of the individuals in each state. We aggregate state employees' data by state and local government employees' data by SMSA to get samples of 49 and 177 observations, respectively. ${ }^{6}$ The data were stratified into education and noneducation employees and, within each of these functions, into four occupational groups: professional and managerial employees (occupation codes [o.c.] 001-199); technical, sales, and administrative-support employees (o.c. 203-389); service employees (including protective service) (o.c. 403-69); and all other employees (including craft, repair, laborer, and transportation-equipment operator) (o.c. 473-889).?

${ }^{6}$ There are three 1980 Census of Population public-use microdata samples (see U.S. Bureau of the Census 1983). The A sample is a $5 \%$ sample; it identifies which state each individual is in and, if he or she is in one of 180 SMSAs, which SMSA. The B sample is a $1 \%$ sample; it identifies whether an individual is in one of 282 SMSAs but not (in most cases) which state. Finally, the C sample is a $1 \%$ sample; it identifies only 27 states separately and no SMSAs. At the time our study was undertaken, only the largest sample, the A sample, was available to us; fortunately, it permitted identification at both the state and the local level. Unfortunately, the data for Colorado (and its three SMSAs) were not available at Cornell University at that time (the tape had broken), hence our sample sizes of 49 states and 177 SMSAs. Researchers considering replicating or extending our analyses in the future might profitably consider merging data from all three samples to increase the number of SMSAs and to reduce sampling variation.

7 Small sample sizes within each cell do not permit further functional disaggregation, and in what follows we ignore the possibility of functional substitution between education and noneducation employees. This assumption has been made by one of us in an earlier study (see Ashenfelter and Ehrenberg 1975); it seems plausible because educational services, especially at the local level, are typically provided by different governmental units than other services are (e.g., by school districts rather than cities). 
For each observation, mean earnings and employment were calculated on a function/occupation/gender breakdown. Given the small sample sizes in each cell, especially for the SMSA sample, these estimates are subject to considerable sampling variability, variability that is exacerbated by the fact that the underlying individual data themselves came from a $5 \%$ sample. ${ }^{8}$

Suppose that within each of these occupational groups the quantity of labor service produced $(L)$ is given by the constant elasticity of substitution function

$$
L=A\left[\delta Q_{M} M^{-B}+(1-\delta) Q_{F} F^{-B}\right]^{-1 / B},
$$

where $Q_{M}\left(Q_{F}\right)$ is a measure of the quality of males (females) employed in the occupation, $M(F)$ is a measure of male (female) employment in the occupation, and $A, B$, and $\delta$ are parameters. If the only cost of labor is the wage rate, it is well-known that cost minimization leads to the relative-demand equation

$$
\log (M / F)=a_{0}+a_{1} \log \left(W_{M} / W_{F}\right)+a_{2} \log \left(Q_{M} / Q_{F}\right),
$$

where $W_{M}\left(W_{F}\right)$ is the male (female) wage, and $a_{1}$ is an estimate of minus the elasticity of substitution between males and females in the occupation.

Table 1 presents estimates for state employees of this relative-demand equation for each of the four occupational groups in education and noneducation. Equations are estimated with both relative employment and relative man-hours as the dependent variable. Each equation includes the logarithm of male to female earnings in the function-occupation cell (LR3) and, as proxies for the relative quality of males and females in the occupation, the logarithms of the ratio of average age (LR4) and average education level (LR5) of males to females in the function-occupation cell. In addition, to control for supply factors, some equations include the logarithm of a measure of the overall male/female wage ratio in the state (LZ1) and the logarithm of the male/female labor force ratio in the state (LZ2). We expect the former to be negatively and the latter positively associated with male/female relative employment in the function-occupation cell.

${ }^{8}$ The reader can refer to the notes to table 2 (below) to get an idea of how small the sample sizes in each cell in the SMSA sample actually are. For example, if we restrict the sample to observations in which there are at least eight males and eight females in the occupation/function cell from which to compute average wages and employment, we lose over three-quarters of the observations on the "all other" employees category. 
Table 1

Within-Occupation Relative Employment and Hours Equations: 1980 Census of Population State Employee Data, by State

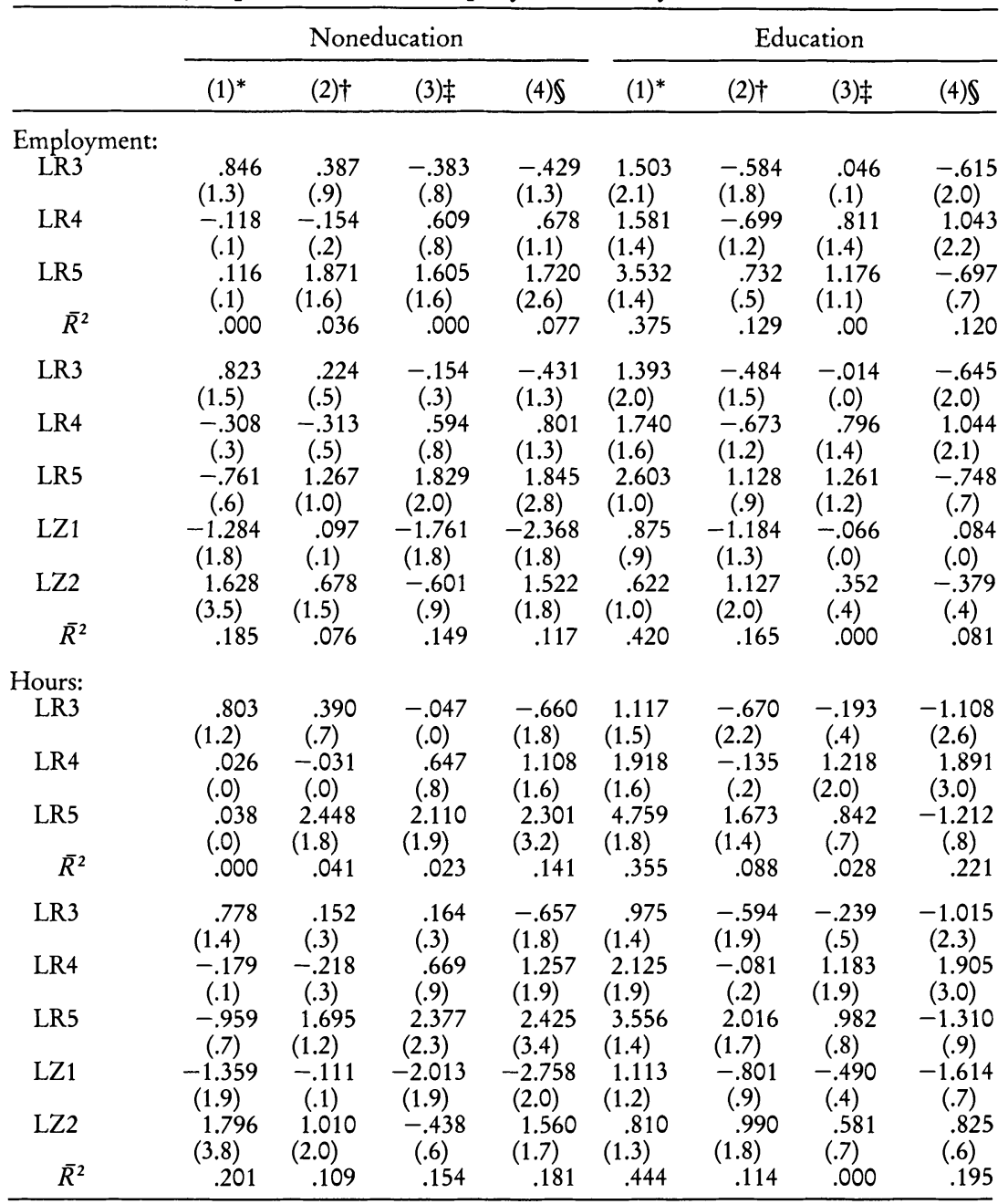

NOTE.-Absolute-value $t$-statistics are in parentheses. LR3 $=$ logarithm of the ratio of average hourly earnings of male employees in the category to average hourly earnings of female employees in the category; LR4 = logarithm of the ratio of the average age of males to the average age of females in the category; LR5 = logarithm of the ratio of average education level of males to the average education level of females in the category; LZ1 = logarithm of the ratio of male mean weekly earnings of full-year full-time workers in the state to female mean weekly earnings of full-year full-time workers in the state; and LZ2 = logarithm of the ratio of male civilian labor force in the state to female civilian labor force in the state.

* Professional and managerial employees.

†Technical, sales, and administrative-support employees.

$¥$ Service employees (including protective service).

$\$$ Other employees (including craft, repair, laborer, and transportation-equipment operators). 
Where statistically significant, the control variables (LR4, LR5, LZ1, and LZ2) all have the expected sign. Unfortunately, the evidence on the substitutability of males for females is much weaker. For noneducation, when relative employment is the dependent variable, there are no significant relative-wage elasticities. When relative man-hours is used (which probably is preferable), male/female substitution appears to occur only in the "other" category, where a $10 \%$ increase in the wage ratio is associated roughly with a $6.5 \%$ decrease in the hours ratio. Elasticities in this range and larger are observed for state employees in education in the technical, sales, and administrative-support and the "other" categories. However, here seemingly perverse positive relative-wage coefficients are found in the professional category.

Table 2 presents estimates of the relative-wage coefficients from similarly specified equations for local government employees, with

Table 2

Within-Occupational Relative Employment and Hours Elasticities with Respect to Relative Wages: 1980 Census of Population Local Employee Data, by SMSA

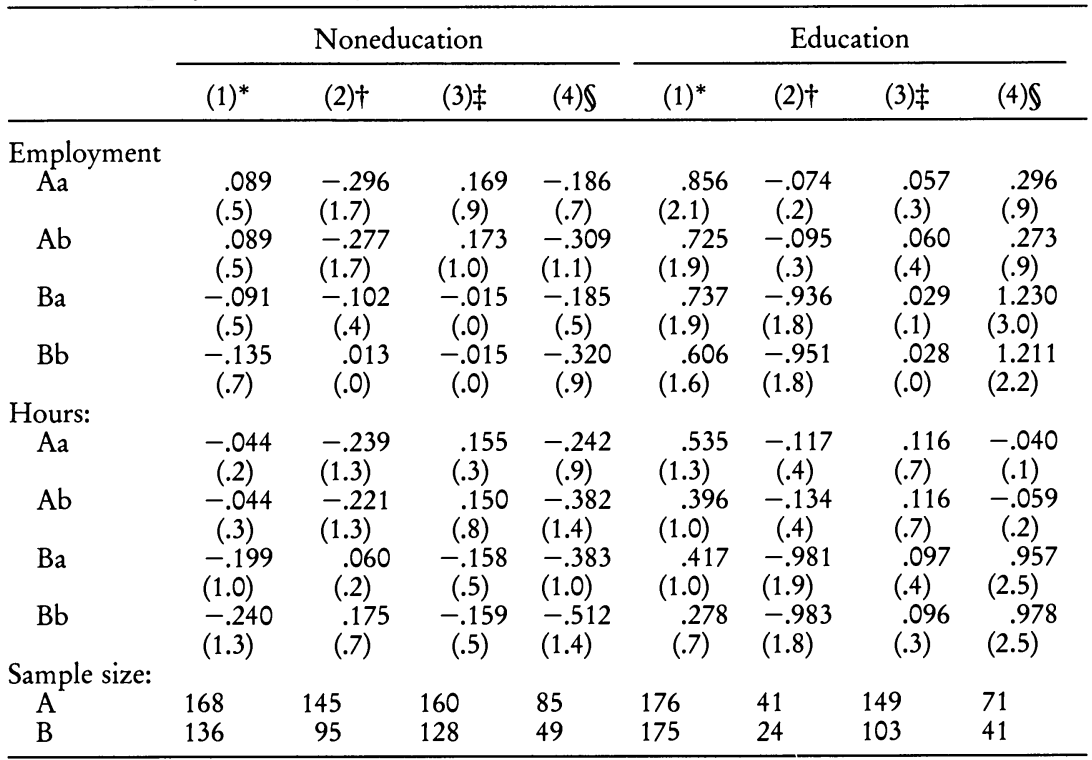

NOTE.-Absolute-value $t$-statistics are in parentheses. $\mathrm{A}=$ confined to SMSAs with more than four males and four females in the occupation in the data; $\mathrm{B}=$ confined to SMSAs with more than eight males and eight females in the occupation in the data; $\mathrm{a}=$ logarithms of relative age and relative education levels also included in the analysis; and $b=$ logarithms of relative age, relative education levels, and male/female labor force ratio included in the analyses.

* Professional and managerial employees.

$\uparrow$ Technical, sales, and administrative-support employees.

$\ddagger$ Service employees (including protective service).

§ Other employees (including craft, repair, laborer, and transportation-equipment operators). 
SMSAs as the units of observation. To avoid errors induced by averages constructed from very small samples, the analyses here are restricted to SMSAs in which at least four (or eight) individuals of each gender were contained in the data for each occupation-function cell. While it would have been preferable to require a larger minimum number of observations in each cell, the tabulation of the resulting sample sizes from those restrictions that is also reported in table 2 suggests that even these restrictions substantially reduced the number of observations available.

The results in table 2 do not strongly support the within-occupation male-female substitution hypothesis. There is some evidence, for both education and noneducation, that substitution takes place among technical and administrative-support employees. However, for education employees, in some specifications relative wages are positively associated with relative employment levels for both the professional and the "other" categories. ${ }^{9}$

Taken together, the results in tables 1 and 2 do not strongly support the hypothesis that within broad occupational groups male/female employment ratios are negatively associated with male/female wage ratios. Whether this reflects the failure of substitution to exist, heterogeneity induced by using broad occupational categories, large sampling errors in the data, or the omission of other important explanatory variables that prevent us from accurately identifying the underlying demand curves is unclear. Unfortunately, sample sizes within cells in these data are usually too small to permit tests of substitutability within finer occupational groups.

If one assumes that substitution between males and females is not possible within these broad occupational groups, one can aggregate across sexes within groups to come up with estimates of the average wage paid in each occupation $\left(w_{i}\right)$. The data also permit the computation of the share of the payroll paid to each occupational group $\left(S_{i}\right)$. One

${ }^{9}$ As a referee has pointed out, one may question whether we have succeeded in identifying a structural relative demand curve in tables 1 and 2 or have merely estimated a reduced form that combines both demand and supply-side forces. In fact, we also estimated structural relative-demand curves in which relative employment was specified to be a function of relative wages and the relativequality variables (LR4 and LR5), and an instrument for relative wages (based on the relative-quality variables and the supply-side variables [LZ1 and LZ2]) was used. The pattern of relative-wage coefficients obtained from this specification was quite similar to that reported in the text (although, as might be expected, the coefficients were less precise) and did not prove any more supportive of the within-occupation male-female substitution hypothesis. Since the data used in the analyses are grouped data, with differing numbers of individuals in each group, we also estimated these models by weighted least squares to try to correct for heteroscedasticity problems. Again, in no case did this substantially alter the pattern of results we obtained. 
can thus estimate share equations (derived from translog expenditure functions) of the form

$$
S_{i}=\sum_{j=1}^{4} a_{i j} \log w_{j}, \quad i=1,2,3,4
$$

to test whether substitution of employees across occupations occurs in response to changes in wages in the different occupations. ${ }^{10}$

If such substitution occurs, given estimates of how CWWA would change the average wage in each occupation, one can then compute the resulting changes in factor shares and, holding the total employment budget constant, the change in total and female employment in each occupation. To these changes, one can add estimates of the employment changes caused by the response of the employment budget to the CWWA-induced change in the average wage in the sector and thus obtain an estimate of the overall effect of CWWA on female employment in the sector.

As is well-known, the output-constant own-wage elasticity of demand $\left(n_{i}\right)$ for each occupation is given by

$$
n_{i}=\frac{a_{i i}+S_{i}^{2}-S_{i}}{S_{i}},
$$

and each of these elasticities should be negative. ${ }^{11}$ In addition, to satisfy the homogeneity property - that a doubling of all wages would not alter the share spent on each occupation-it is necessary that

$$
a_{j 1}+a_{j 2}+a_{j 3}+a_{j 4}=0
$$

for each $j$. Finally, to satisfy the symmetry property-that the Allen elasticity of substitution of occupation $i$ for occupation $j$ be equal to the elasticity of occupation $j$ for occupation $i$-it must be the case that

$$
a_{i j}=a_{j i}
$$

for all $i \neq j$. The restrictions summarized in (4)-(6) provide a convenient

${ }^{10}$ Implicit in this formulation is the notion that public-sector decision makers have well-defined utility functions that depend on the per capita employment levels of various categories of public employees and that the parameters of these functions do not vary systematically with public-employee wages across areas. For discussions of this approach and analyses that use functional rather than occupational data, see Ehrenberg (1973) and Ashenfelter and Ehrenberg (1975).

${ }^{11}$ See Hamermesh (in press). 
way of testing whether the data are consistent with the share equations specified in equation (3).

Tables 3 and 4 provide estimates, for the state and local government samples, respectively, of the occupational share equations derived from the translog expenditure function. In each case estimates are provided of the unconstrained system, of the system with homogeneity imposed, and of the system with both homogeneity and symmetry imposed. Since the four occupational shares must sum to unity, the coefficients of any wage variable must sum across equations in each system to zero. Hence we infer the value of the coefficients of the last equation from estimates of the first three. The estimates are obtained using an instrument for each of the wage variables and an estimation method that takes account of the correlation of the error terms across equations. ${ }^{12}$

These estimates provide mixed support for the translog specification. On the one hand, in three of the four systems (education/state, noneducation/state, education/local) one cannot reject the hypothesis that the homogeneity and symmetry restrictions-(5) and (6)-are satisfied. On the other hand, the majority of the individual regression coefficients are statistically insignificantly different from zero in all the systems estimated. One senses that this contributes to the above results. Moreover,

${ }^{12}$ The need for instrumental variables can be illustrated in the two-occupation case. Let $M_{i}\left(F_{i}\right)$ be the number of male (female) hours employed in occupation $i$ and $W_{M i}\left(W_{F i}\right)$ the wage rate of males (females) in occupation $i$. Then the shares $\left(S_{i}\right)$ and average wages $\left(W_{i}\right)$ in the two occupations are given by

$$
\begin{aligned}
S_{1} & =\frac{W_{M 1} M_{1}+W_{F 1} F_{1}}{W_{M 1} M_{1}+W_{F 1} F_{1}+W_{M 2} M_{2}+W_{F 2} F_{2}}, \\
S_{2} & =\frac{W_{M 2} M_{2}+W_{F 2} F_{2}}{W_{M 1} M_{1}+W_{F 1} F_{1}+W_{M 2} M_{2}+W_{F 2} F_{2}}, \\
W_{1} & =\frac{W_{M 1} M_{1}+W_{F 1} F_{1}}{M_{1}+F_{1}}, \\
W_{2} & =\frac{W_{M 2} M_{2}+W_{F 2} F_{2}}{M_{2}+F_{2}} .
\end{aligned}
$$

It is obvious that each $S_{i}$ is positively correlated with its own wage rate and negatively correlated with the other wage rate; these correlations would bias the coefficient estimates of eq. (3). To remove these mechanical correlations, instruments for the occupational wage rates are created by regressing these wage rates on median income in the area, area population, male and female wages in the area (state data only), and mean ages and education levels of males and females in the occupation. The system is then estimated using the three-stage least squares option in the SAS statistical package. Use of weighted least squares to correct for heteroscedasticity again did not yield substantially different results, so only the unweighted results are reported here. 
Table 3

Estimates of State Government Translog Cost Functions State Major Occupation Group Data: Instrumental Variables

\begin{tabular}{|c|c|c|c|c|c|c|c|c|}
\hline & \multicolumn{4}{|c|}{ Education* } & \multicolumn{4}{|c|}{ Noneducation $\dagger$} \\
\hline & LW1 & LW2 & LW3 & LW4 & LW1 & LW2 & LW3 & LW4 \\
\hline \multicolumn{9}{|c|}{ I. No restrictions: } \\
\hline S1 & .196 & .034 & -.183 & -.220 & -.277 & -1.802 & 1.367 & -.067 \\
\hline S2 & $\begin{array}{l}-.005 \\
(.0)\end{array}$ & $\begin{array}{c}-.085 \\
(.7)\end{array}$ & $\begin{array}{l}.022 \\
(.2)\end{array}$ & $\begin{array}{c}.041 \\
(.3)\end{array}$ & $\begin{array}{l}.212 \\
(.5)\end{array}$ & $\begin{array}{l}.179 \\
(.6)\end{array}$ & $\begin{array}{c}.184 \\
(.4)\end{array}$ & $\begin{array}{c}-.062 \\
(.3)\end{array}$ \\
\hline S3 & -.136 & -.201 & -.204 & .056 & .549 & 1.209 & -.922 & -.038 \\
\hline $\mathrm{S} 4 \ddagger$ & -.054 & -.065 & -.043 & . 123 & $\begin{array}{l}(.4) \\
-.484\end{array}$ & $\begin{array}{l}(1.2) \\
.596\end{array}$ & $\begin{array}{l}(.6) \\
-.261\end{array}$ & $\begin{array}{l}(.0) \\
.167\end{array}$ \\
\hline \multicolumn{9}{|c|}{ II. Homogeneity: } \\
\hline S1 & $\begin{array}{c}-.088 \\
(.5)\end{array}$ & $\begin{array}{l}.340 \\
(1.8)\end{array}$ & $\begin{array}{l}-.183 \\
(1.0)\end{array}$ & $\begin{array}{c}-.068 \\
(.3)\end{array}$ & $\begin{array}{l}.934 \\
(.9)\end{array}$ & $\begin{array}{c}-1.142 \\
(1.2)\end{array}$ & $\begin{array}{c}-.224 \\
(.5)\end{array}$ & $\begin{array}{l}.432 \\
(.7)\end{array}$ \\
\hline S2 & $\begin{array}{l}.052 \\
\text { (.4) }\end{array}$ & $\begin{array}{c}-.085 \\
(.7)\end{array}$ & .022 & .010 & -.012 & .056 & .112 & -.155 \\
\hline S3 & .027 & -.201 & .204 & -.030 & -.408 & .506 & .336 & -.434 \\
\hline $\mathrm{S} 4 \pm$ & $(.3)$ & $(2.3)$ & $(2.4)$ & $(.4)$ & $(.6)$ & (.8) & $(1.0)$ & $(1.0)$ \\
\hline \multicolumn{9}{|c|}{ III. Homogeneity and symmetry: } \\
\hline S1 & $\begin{array}{l}.045 \\
(.2)\end{array}$ & $\begin{array}{l}.061 \\
(.5)\end{array}$ & $\begin{array}{l}-.066 \\
(1.0)\end{array}$ & $\begin{array}{c}-.039 \\
(.8)\end{array}$ & $\begin{array}{c}-.039 \\
(.1)\end{array}$ & -.138 & $\begin{array}{l}.052 \\
(2)\end{array}$ & $\begin{array}{l}.126 \\
(8)\end{array}$ \\
\hline S2 & .061 & -.004 & -.076 & .020 & -.138 & .122 & .017 & -.001 \\
\hline S3 & -.066 & -.079 & .201 & -.057 & .052 & .017 & .175 & -.243 \\
\hline & $(1.0)$ & $(1.3)$ & $(4.1)$ & $(1.7)$ & $(.2)$ & (.1) & $(1.0)$ & $(2.1)$ \\
\hline S4 $\ddagger$ & -.039 & .020 & -.057 & .076 & .126 & -.001 & -.243 & .118 \\
\hline
\end{tabular}

NOTE.-Absolute-value $t$-statistics are in parentheses. $N=49 . \mathrm{LW} 1=$ logarithm of the average hourly wage in category $1 ; \mathrm{LW} 2=$ logarithm of the average hourly wage in category $2 ; \mathrm{LW} 3=$ logarithm of the average hourly wage in category $3 ; \mathrm{LW} 4=$ logarithm of the average hourly wage in category $4 ; \mathrm{S} 1=$ share of payroll spent on professional and managerial employees; S2 = share of payroll spent on technical, sales, and administrative support employees; S3 $=$ share of payroll spent on service employees; $\mathrm{S} 4=$ share of payroll spent on all other employees.

${ }^{*} F(3,132)=1.46$ (with the null hypothesis of homogeneity and the alternative hypothesis of no restrictions) and $F(6,132)=1.72$ (with the null hypothesis of homogeneity and symmetry and the alternative hypothesis of no restrictions).

$\dagger F(3,132)=0.57$ (with the null hypothesis of homogeneity and the alternative hypothesis of no restrictions) and $F(6,132)=1.70$ (with the null hypothesis of homogeneity and symmetry and the alternative hypothesis of no restrictions).

$\ddagger$ Estimates are implied by the adding up property. 
Table 4

Estimates of Local Government Translog Cost Functions SMSA Level Major Occupational Group Data: Instrumental Variables

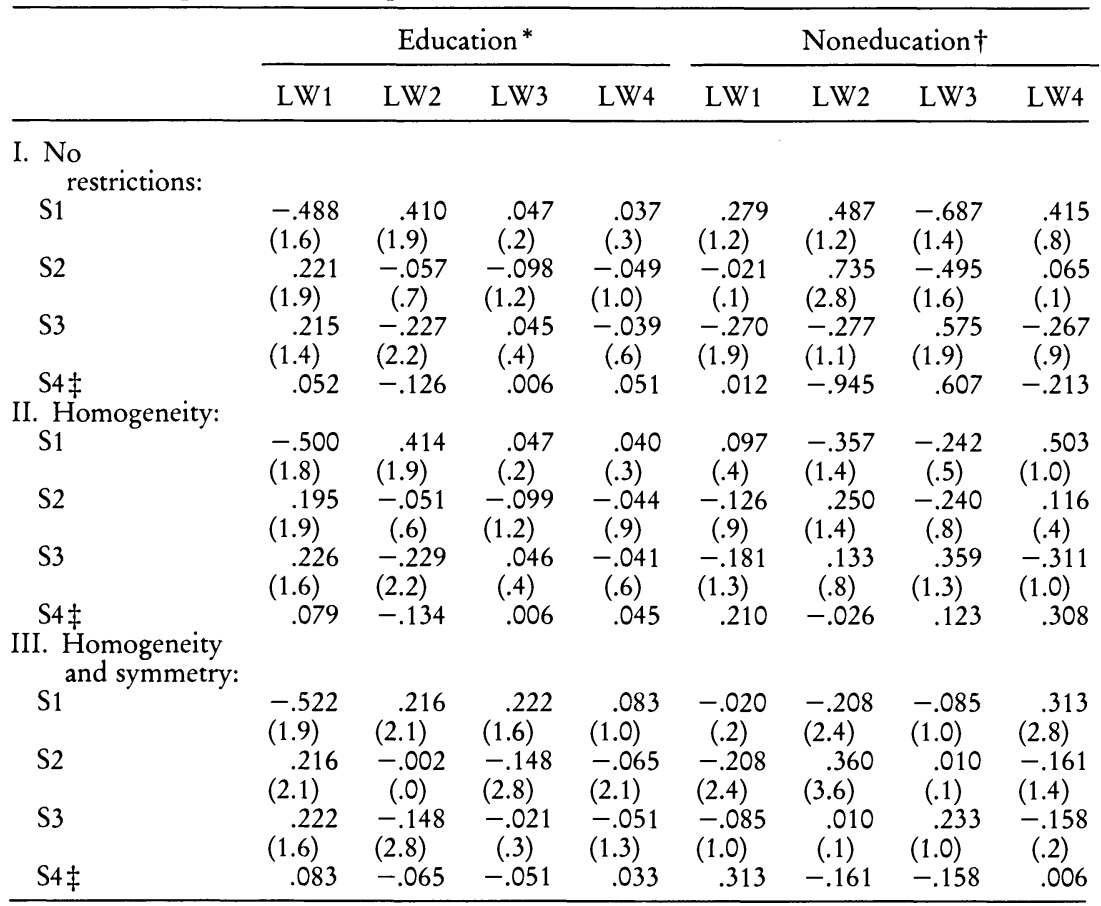

NOTE.-Absoute-value $t$-statistics are in parentheses. $N=177$. LW1 $=$ logarithm of the average hourly wage in category $1 ; \mathrm{LW} 2=\operatorname{logarithm}$ of the average hourly wage in category $2 ; \mathrm{LW} 3=\operatorname{logarithm}$ of the average hourly wage in category $3 ; \mathrm{LW} 4=\log$ arithm of the average hourly wage in category $4 ; \mathrm{S} 1=$ share of payroll spent on professional and managerial employees; $\mathbf{S} 2=$ share of payroll spent on technical, sales, and administrative support employees; $\mathrm{S} 3=$ share of payroll spent on service employees; $\mathrm{S} 4=$ share of payroll spent on all other employees.

${ }^{*} F(3,516)=0.93$ (with the null hypothesis of homogeneity and the alternative hypothesis of no restrictions) and $F(6,516)=0.89$ (with the null hypothesis of homogeneity and symmetry and the alternative hypothesis of no restrictions).

$\dagger F(3,516)=4.47$ (with the null hypothesis of homogeneity [rejected at the .05 level] and the alternative hypothesis of no restrictions) and $F(6,516)=2.52$ (with the null hypothesis of homogeneity and symmetry [rejected at the .05 level] and the alternative hypothesis of no restrictions).

$\ddagger$ Estimates are implied by the adding up property.

the own-wage elasticities of demand that are implied when symmetry and homogeneity are imposed (table 5) are negative in only nine of the 16 cases.

\section{Simulated Effects on Female Employment of a CWWA Policy}

The mixed nature of the above results suggests that one should take predictions they generate with a grain of salt. Nonetheless, this section illustrates how they can be used-along with knowledge of the share of 
Table 5

Estimates of Own Wage Elasticities of Demand for State and Local Government Employees by Occupation

\begin{tabular}{|c|c|c|c|c|}
\hline & \multicolumn{2}{|c|}{ State Government } & \multicolumn{2}{|c|}{ Local Government } \\
\hline & Education & Noneducation & Education & Noneducation \\
\hline $\begin{array}{l}\text { Professional and managerial } \\
\text { employees }\end{array}$ & $\begin{array}{l}-.207 \\
(.731)\end{array}$ & $\begin{aligned}-.633 \\
(.453)\end{aligned}$ & $\begin{array}{c}-.816^{*} \\
(.820)\end{array}$ & $\begin{array}{l}-.791 \\
(.280)\end{array}$ \\
\hline $\begin{array}{l}\text { Technical, sales, and } \\
\text { administrative-support } \\
\text { personnel }\end{array}$ & $\begin{array}{r}-.880 \\
(.147)\end{array}$ & $\begin{array}{c}-.276 \\
(.267)\end{array}$ & $\begin{array}{c}-.961 \\
(.068)\end{array}$ & $\begin{array}{c}.961 \\
(.205)\end{array}$ \\
\hline Service employees & $\begin{array}{l}1.593^{*} \\
(.080)\end{array}$ & $\begin{array}{l}.303 \\
(.152)\end{array}$ & $\begin{array}{r}-1.191 \\
(.078)\end{array}$ & $\begin{array}{l}.750 \\
(.301)\end{array}$ \\
\hline Other employees & $\begin{array}{l}.850 \\
(.042)\end{array}$ & $\begin{array}{l}.050 \\
(.128)\end{array}$ & $\begin{array}{l}.005 \\
(.034)\end{array}$ & $\begin{array}{l}-.757 \\
(.214)\end{array}$ \\
\hline
\end{tabular}

NOTE.-Derived from own wage coefficients in tables 3 and 4 (homogeneity and symmetry constrained specifications), mean share of payroll spent on the category, and equation (4) in the text. Mean share of payroll is in parentheses.

${ }^{*}$ Estimated based on statistically significant regression coefficient.

expenditures on each category, the proportion of hours worked by females in each category, the male and female wages in each category, female employment in each category, and an assumption about what CWWA would do to female wages - to generate predictions about the effect of CWWA on female employment due to substitution away from female-dominated occupations, holding the total employment budget constant. The Appendix sketches somewhat formally how this is done. Illustrative simulations appear in table 6 , where we have assumed that CWWA would raise the wage of all female employees by $20 \% .{ }^{13}$

Although the implied percentage change in female employment in each occupation varies across function (education or noneducation) and sector (state or local), the implied average change in overall female employment is remarkably similar across function and sector. A $20 \%$ increase in female wages is predicted to reduce female employment in education by almost $6 \%$ and female employment in noneducation by about $5.5 \%$. These figures are the averages for all observations in the sample; as the bottom rows of table 6 suggest, the predicted losses vary across observations, with the range of predicted losses being larger for local government employees. ${ }^{14}$

${ }^{13}$ This figure is in the range of the wage-gap estimates between comparable males and females that we obtained in our analyses of formal job-evaluation data for state employees in Connecticut, Minnesota, and Washington; see Ehrenberg and Smith (in press) for details. A lower figure would yield proportionately lower employment-loss estimates.

${ }^{14}$ The App. also indicates how one can compute the male percentage employment loss in each sector. While we have not computed these for each observation 
Table 6

Implied Percentage Effects of a $20 \%$ CWWA for All Females on the Employment of Females in State and Local Governments due to Occupational Substitution: Total Employment Budget Held Constant

\begin{tabular}{|c|c|c|c|c|}
\hline & \multicolumn{2}{|c|}{ State Employees } & \multicolumn{2}{|c|}{ Local Employees } \\
\hline & Education & Noneducation & Education & Noneducation \\
\hline \multicolumn{5}{|l|}{$\begin{array}{l}\text { Mean percentage change in female } \\
\text { employment in: }\end{array}$} \\
\hline $\begin{array}{l}\text { Professional and managerial } \\
\text { employees }\end{array}$ & -6.2 & -8.7 & -15.6 & -12.5 \\
\hline $\begin{array}{l}\text { Technical, sales, and } \\
\text { administrative-support }\end{array}$ & & & & \\
\hline personnel & -4.9 & -6.8 & 21.5 & -3.9 \\
\hline Service employees & -6.0 & 2.8 & 14.4 & -2.2 \\
\hline Other employees & -7.4 & 2.6 & 10.4 & 5.5 \\
\hline Overall & -5.9 & -5.5 & -5.9 & -5.4 \\
\hline Minimum change observation & -4.3 & -3.3 & -1.3 & .1 \\
\hline Maximum change observation & -9.3 & -7.1 & -12.1 & -11.9 \\
\hline
\end{tabular}

SOURCE.-Authors' calculations using the method described in the App., the coefficients from the homogeneity and symmetry constrained regressions reported in tables 3 and 4 , and the underlying census data.

We must stress, however, that these simulations assume that the total employment budget remains constant in the face of the CWWA. This is roughly equivalent to assuming that in the aggregate the wage elasticity of demand for state and local government employees is unity. That is, they assume that any given increase in the average wage of state and local government employees would result in an equal percentage decrease in aggregate state and local government employment.

In fact, studies of the aggregate (by function) wage elasticity of demand for state and local government employees typically find wage elasticities of demand that are less than unity. ${ }^{15}$ Thus an increase in the average wage would increase the total employment budget; the calculations in table 6 therefore overstate the decline in female employment that would occur.

Some idea of the magnitude of the overstatement can be obtained from the following crude calculations. On the basis of knowledge of the ratios of male to female wages and of male to female hours in each function/sector, we calculate that a $20 \%$ increase in wages for females would increase the average wages of state education, state noneducation,

and then taken the average of the losses across all observations, it is interesting to note that computations using the average male employment shares (across all observations) in the sample yielded losses that were similar in magnitude to the females' losses for education but somewhat smaller (2\%-3\%) for noneducation.

${ }^{15}$ For a summary of the results from all these studies, see Ehrenberg and Schwarz (in press, table 3 ). 
local education, and local noneducation employees by about $8 \%, 7.5 \%$, $11.5 \%$, and $5.5 \%$, respectively. ${ }^{16}$ It is reasonable to take -.5 as a "best" estimate of the aggregate-wage elasticity of demand for noneducational employees in the state and local sector and -.75 as the comparable estimate for educational employees. ${ }^{17}$ These elasticities imply employmentbudget increases for state education, state noneducation, local education, and local noneducation, respectively, of $2 \%, 3.75 \%, 2.9 \%$, and $2.75 \%$. Such increases would reduce the female employment declines predicted in table 6 by roughly half.

\section{Concluding Remarks}

Taken at face value, our simulations suggest that the decline in female employment in the state and local sector caused by a $20 \%$ CWWA for all female employees in the state and local sectors would be quite small, probably falling in the range of $2 \%-3 \% .{ }^{18}$ These somewhat surprisingly small estimates are a direct result of our inability to find much substitutability of males for females within major occupational groups or much substitutability across major occupational groups as relative wages change.

We do not place much confidence in these estimates, however, because in general they are based on statistically insignificant coefficient estimates. Whether the latter are due to heterogeneity induced by using broad occupational categories, large sampling errors in the underlying data, a failure to identify demand equations from these data, or our use of incorrect functional forms is unclear. ${ }^{19}$ Hence, until future research narrows our uncertainty about these estimates, we do not intend that policymakers place very much weight on them. Rather, we view the contribution of our paper as laying out a methodological approach for analyzing possible adverse employment effect of implementing comparable worth, an approach that might serve as a starting point for future empirical studies. ${ }^{20}$

${ }^{16}$ These are crude calculations that ignore the interoccupational substitution that would take place.

${ }^{17}$ Ehrenberg and Schwarz (in press, table 3).

${ }^{18}$ It is interesting to note that a related study of legislated wage increases for females in Australia (Gregory and Duncan 1981) found much smaller resulting decreases in the rate of female employment growth in the public sector than in the private sector.

${ }^{19}$ With respect to the latter point, we made no attempt to test whether functional forms other than the constant elasticity of substitution (withinoccupation analyses) and the translog (across-occupation analyses) "fit" the data better or even whether the implicit assumption of constant returns to scale was correct.

${ }^{20}$ Future researchers might consider using different functional forms and collecting additional variables that might permit improved identification of the demand equations. They also might consider merging data from the A, B, and C samples of the 1980 Census of Population to expand both the number of 
We should also stress that a comparable-worth policy would have additional labor market repercussions. Some males in the sector would also lose their jobs, and, if these displaced males and females seek employment in the private sector, downward pressure will be placed on wages there. If a CWWA policy were confined to the public sector and displacement occurred, it is not obvious that women as a group would benefit; the higher wages for women employed in the public sector may be at least partially offset by resulting lower wages for women in the private sector.

Alternatively, the policy might induce some of the displaced females to remain "attached" to the state and local sector in the hope of obtaining a now higher-paying job there in the future. Thus the policy might lead to "wait unemployment" among females. As is well-known, in this case the increase in female unemployment may exceed the number of females displaced by the increase in female wages in the public sector, and the direction that the female wage in the private sector would move would depend on demand elasticities in both sectors. ${ }^{21}$

Of course, just as our simulations ignore spillover or queuing effects on private-sector labor markets, they also ignore the repercussions on the private sector of the method of funding comparable-worth wage increases. Throughout, we have assumed that such increases would not substitute for wage increases that public employees would otherwise receive, that is, that they would lead to an increase in the average wage in the public sector. As noted above, wage elasticities of demand in the state and local sector tend to be inelastic. Thus either higher state and local taxes or reductions in other state and local expenditures would be required to fund CWWA. Either of these events would have repercussions on employment in the private sector.

\section{Appendix}

\section{Estimating Female Employment Losses Caused by CWWA due to Changes in the Occupational Mix}

Let $W_{M j}$ be the wage of males in occupation $j, W_{F j}$ the wage of females in occupation $j$, and $P_{j}$ the proportion of hours worked by females in the occupation. The average wage in the occupation, $W_{j}$, is given by

SMSAs in the sample and the number of individuals observed in each state and SMSA. Finally, to avoid problems associated with the aggregation of governmental units and sampling, they might consider using alternative data files such as the Equal Employment Opportunity Commission's EEO-4 data, an annual survey of all state and local governments that contains data by function, occupation, and gender. However, these data are not currently available publicly, and they have their own problems. Some of these problems are discussed by us elsewhere (Ehrenberg, Smith, and Straka 1986); this report is available on request.

${ }^{21}$ For a more extended discussion of wait unemployment that draws heavily on Mincer (1976), see Ehrenberg and Smith (1985, chap. 12). 


$$
W_{j}=W_{M j}\left(1-P_{j}\right)+W_{F j} P_{j}
$$

Differentiating with respect to the female wage and then multiplying both sides by the ratio of the female wage to the average wage, one obtains

$$
\left(\partial W_{j} / \partial W_{F j}\right)\left(W_{F j} / W_{j}\right)=\frac{P_{j} W_{F j}}{P_{j} W_{F j}+\left(1-P_{j}\right) W_{M j}}
$$

or

$$
\% \Delta W_{j} \approx \% \Delta W_{F j} \frac{P_{j}}{P_{j}+\left(1-P_{j}\right)\left(W_{M j} / W_{F j}\right)} .
$$

If CWWA lead to the same percentage increase in female wages in each occupation, $c$, then the percentage change they induce in the average wage in occupation $j$ is

$$
\% \Delta W_{j} \approx \frac{c P_{j}}{P_{j}+\left(1-P_{j}\right)\left(W_{M j} / W_{F j}\right)} .
$$

Now from the translog cost-function share equation (3) in the text

$$
d S_{i}=\sum_{j=1}^{4} a_{i j} d \log W_{j} \approx \sum_{j=1}^{4} a_{i j}\left(\% \Delta W_{j}\right) .
$$

The share of expenditures spent on each occupational category is given by

$$
S_{i}=W_{i} E_{i} / \sum_{j=1}^{4} W_{j} E_{j}
$$

where employment in each occupation, $E_{j}$, is measured in man-hours. If the total employment budget-the denominator of (A6) - is held constant, taking the logarithm of both sides and then the total differential, one obtains

$$
\left(1 / S_{i}\right) d S_{i}=d \log S_{i}=d \log W_{i}+d \log E_{i} \approx \% \Delta W_{i}+\% E_{i} .
$$

One can substitute (A5) into (A7) and solve for $\% \Delta E_{i}$ to obtain

$$
\% \Delta E_{i} \approx\left[\left(1 / S_{i}\right) \sum_{j=1}^{4} a_{i j}\left(\% \Delta W_{j}\right)\right]-\% \Delta W_{i} .
$$

Equations (A4) and (A8) together yield the predicted percentage change in total employment in each occupation induced by the CWWA. 
How would female employment change? Since we have assumed (on the basis of the results in tables 1 and 2) that CWWA would lead to no male/female substitution within an occupation, female employment would change in each occupation by the same percentage as total employment. As a result, if $E_{F j}$ is the initial level of female employment in occupation $j$ (measured in hours), the overall percentage effect on female employment due to the changing occupational mix $\left(\% \Delta E_{F}\right)$ is given by

$$
\% \Delta E_{F}=\sum_{j=1}^{4}\left(\% \Delta E_{j}\right) E_{F j} / \sum_{j=1}^{4} E_{F j}
$$

Similarly, the overall percentage effects on males' employment due to the changing occupational mix $\left(\% \Delta E_{M}\right)$, is given by

$$
\% \Delta E_{M}=\sum_{j=1}^{4}\left(\% \Delta E_{j}\right) E_{M j} / \sum_{j=1}^{4} E_{M j}
$$

where $E_{M j}$ is the initial level of male employment in occupation $j$.

\section{References}

Ashenfelter, Orley, and Ehrenberg, Ronald G. "The Demand for Labor in the Public Sector." In Labor in the Public and Nonprofit Sectors, edited by Daniel S. Hamermesh. Princeton, N.J.: Princeton University Press, 1975.

Cook, Alice. Comparable Worth: The Problem and States' Approaches to Wage Equity. Honolulu: University of Hawaii at Manoa, Industrial Relations Center, February 1983.

Ehrenberg, Ronald G. "The Demand for State and Local Government Employees." American Economic Review 63 (June 1973): 366-79.

Ehrenberg, Ronald G., and Schwarz, Joshua. "Public Sector Labor Markets." In Handbook of Labor Economics, edited by Orely Ashenfelter and Richard Layard. New York: Elsevier-North Holland, in press.

Ehrenberg, Ronald G., and Smith, Robert S. Modern Labor Economics. 2d ed. Glenview, Ill.: Scott, Foresman, 1985.

- "Comparable Worth in the Public Sector." Public Compensation, edited by David Wise. Chicago: University of Chicago Press, in press. Ehrenberg, Ronald G.; Smith, Robert S.; and Straka, John W. "Implementing Comparable Worth in the Public Sector: Some Analyses Using EEO-4 Data." Final report submitted to the Equal Employment Opportunity Commission, Washington, D.C., January 1986.

Gregory, Robert, and Duncan, Robert. "Segmented Labor Market Theories and the Australian Experience of Equal Pay for Women." Journal of Post Keynesian Economics 3 (Spring 1981): 403-29.

Hamermesh, Daniel. "The Demand for Labor in the Long Run." In Handbook of Labor Economics, edited by Orley Ashenfelter and Richard Layard. New York: Elsevier-North Holland, in press. 
Mincer, Jacob. "Unemployment Effects of Minimum Wages." Journal of Political Economy 84, no. 4, pt. 2 (July/August 1976): S87-S104.

National Committee on Pay Equity. Who's Working for Working Women: A Survey of State and Local Government Pay Equity Activities and Initiatives. Washington, D.C.: National Commission on Pay Equity, 1984.

Treiman, Donald J., and Hartmann, Heidi, eds. Women, Work, and Wages: Equal Pay for Jobs of Equal Value. Washington, D.C.: National Academy Press, 1981.

U.S. Bureau of the Census. 1980 Census of Population and Housing. Public-Use Microdata Samples-Technical Documentation. Washington, D.C.: U.S. Bureau of the Census, 1983.

U.S. Department of Labor. Bureau of Labor Statistics. Employment and Earnings. Vol. 30. Washington, D.C.: U.S. Government Printing Office, March 1983. 